\title{
Erratum to: 'Prophylaxis and management of postoperative nausea and vomiting in enhanced recovery protocols'
}

Ruchir Gupta ${ }^{1 *}$ and Roy Soto ${ }^{2}$

\section{Erratum}

Unfortunately, the original version of this article (Gupta \& Soto 2016) contained an error. The title was stated incorrectly. The original title: "Prophylaxis and management of postoperative nausea and vomiting in enhanced recovery protocols: Expert Opinion statement from the American Society for Enhanced Recovery (ASER) " should be "Prophylaxis and management of postoperative nausea and vomiting in enhanced recovery protocols"

\section{Author details}

'Stony Brook University School of Medicine, Stony Brook, NY, USA. ${ }^{2}$ Oakland

University William Beaumont School of Medicine, Royal Oak, MI, USA.

Received: 19 April 2016 Accepted: 20 April 2016

Published online: 03 May 2016

\section{Reference}

Gupta, Soto. Perioper Med. 2016;5:4. doi:10.1186/s13741-016-0029-0.

* Correspondence: guptar2005@yahoo.com

'Stony Brook University School of Medicine, Stony Brook, NY, USA

Full list of author information is available at the end of the article

\footnotetext{
Submit your next manuscript to BioMed Central and we will help you at every step:

- We accept pre-submission inquiries

- Our selector tool helps you to find the most relevant journal

- We provide round the clock customer support

- Convenient online submission

- Thorough peer review

- Inclusion in PubMed and all major indexing services

- Maximum visibility for your research
}

Submit your manuscript at www.biomedcentral.com/submit 